\title{
Cytotoxic Activity of the Root of Euphorbia Tehranica Ethanolic Extract Against Caco-2 Colorectal Cancer Cell Line
}

DOI: 10.30699 /acadpub.mci.2.2.1

Submitted: 2 February 2018

Revised: 15 March 2018

Accepted: 23 March 2018

e-Published: 1 April 2018

Keywords:

Euphorbia Tehranica

Ethanolic Extract

Caco-2

Anticancer Activity
Flora Forouzesh ${ }^{1, *}$, Vahideh Sadeghi ${ }^{1}$, Kaveh Baghaei ${ }^{2}$, Elham Rajabbeigi ${ }^{3}$, Ehsan Nazemalhosseini-Mojarad ${ }^{4, "}$

${ }^{I}$ Department of Genetics, Tehran Medical Sciences Branch, Islamic Azad University, Tehran, Iran

${ }^{2}$ Basic and Molecular Epidemiology of Gastrointestinal Disorders Research Center, Research Institute for Gastroenterology and Liver Diseases, Shahid Beheshti University of Medical Sciences, Tehran, Iran

${ }^{3}$ Department of Biology, Tehran Medical Sciences Branch, Islamic Azad University, Tehran, Iran

${ }^{4}$ Gastroenterology and Liver Diseases Research Center, Research Institute for Gastroenterology and Liver Diseases, Shahid Beheshti University of Medical Sciences, Tehran, Iran

*Corresponding authors: Flora Forouzesh, Department of Genetics, Tehran Medical Sciences Branch, Islamic Azad University, Tehran, Iran. E-mail:f8forouzesh@gmail.com

Ehsan Nazemalhosseini-Mojarad, Gastroenterology and Liver Diseases Research Center, Research Institute for Gastroenterology and Liver Diseases, Shahid Beheshti University of Medical Sciences, Tehran, Iran. E-mail: ehsanmojarad@gmail.com 


\section{INTRODUCTION}

Constituents of several medicinal plants are used since ancient times to treat a variety of diseases. Approximately 70,000 plant species are used for medicinal purposes [1]. The genus Euphorbia is the largest in the plant family Euphorbiaceae, containing about 2000 known species (from annuals to trees). They have unique flower structures, and the all contain latex [2]. Some of the species are used in the cure of migraines, skin diseases, warts, wounds, intestinal parasites, and gonorrhea, in the world. Euphorbia genus has a wide variety of terpenoids (mono, sesqui, and diterpenes to triterpenoids and steroids). Many of these compounds are investigated for their therapeutic effects or their toxicity activity, and some of them are used as medicines [3]. Also, the biological activities of them are antiproliferation, antiviral, antimicrobial, modulability of multidrug resistance, cytotoxic, antifeedant, antidiarrheal, molluscicidal activities $[4,5]$.

Over 80 species of Euphorbia are so far reported from Iran, out of which a few of them are naturalized and the rest are native [6-12]. One of them is $E u$ phorbia teheranica. E. teheranica Boiss. (Euphorbiaceae) is a plant widespread in the Tehran region and semi-desert areas of central Iran [13].

Colorectal cancer (CRC) is one of the major cause of death in worldwide [14] and accounts for over $9 \%$ of all cancer incidence $[15,16]$ so, CRC is the third most common cancer worldwide [16]. Also, it is the third most common cancer in Iran. The incidence of CRC varies in different regions of the world and it varies at least 10 times in different regions and has a significant time trend $[17,18]$. Recent studa ies showed a rapid rise in the incidence of colorectal cancer in Iran $[19,20]$. There are similar incidence rates for cancer of the colon in both genders, and a slight male predominance for rectal cancer $[16,21$, 22]. Local treatments such as surgical or radio-there apy make it difficult to cure or prevent recurrence and metastasis of tumor. Hence, the attempt for safe and effective anticancer drugs from natural plants is an important aspect of anticancer investigation [23]. The current study aimed at evaluating the antitumor properties of the root of E. tehranica ethanolic extract against Caco-2 human colon cancer cell-line.

\section{METHODS}

\section{Plant Material}

Euphorbia tehranica was collected from Tehran (Koohsar Park), Iran, in July 2015. The plant was identified by Dr. Shahin Zare in University of Teh- ran. The specimen (herbarium No. 39917) was deposited in the herbarium of the mentioned center. The roots of plants were dried in a shaded place and then, powdered for later use.

\section{Extraction and Isolation}

Plant material was extracted with absolute ethanol and shaken for 24 hours, then was filtered through number 11 Whatman filter paper. The entire extract was roto-evaporated at $40^{\circ} \mathrm{C}$ and was stored in the dark at $-20^{\circ} \mathrm{C}$ until use [24]. The dried mass was dissolved in absolute ethanol for assays. Treatment doses of extracts were $25,50,100,200,300,400,500$, $600,700,800,900,1000$, and $1200 \mu \mathrm{g} / \mathrm{mL}$.

\section{Cell Culture}

The human colorectal cell-line Caco-2 (adenocarcinoma) was purchased from National Cell Bank of Iran affiliated to Pasteur Institute of Iran, Tehran, Iran and cultured in Dulbecco's modified Eagle's medium (DMEM) (Gibco-USA) supplemented with $100 \mathrm{U} / \mathrm{mL}$ penicillin (Sigma-USA), $100 \mu \mathrm{g} / \mathrm{mL}$ streptomycin (Sigma-USA), and 10\% fetal bovine serum (Gibco-USA). The cells incubated at $37{ }^{\circ} \mathrm{C}$ in $5 \% \mathrm{CO}_{2}$ atmosphere. The cells were sub-cultured and exponential-phase cells were used throughout the experiments.

\section{Ethanolic Extract Treatment}

A total of $80 \times 10^{3}$ dissociated Caco 2 cells were plated in 96-well microplates for 24 hours, and 48 hours incubation for toxicity assays. Before testing, the stock solution was prepared in 100\% ethanol (Sigma-USA) and diluted into medium to the concentrations in demand. Control cultures received only ethanol. Also, untreated cells were used as the negative control.

\section{Cell Viability Assessment Assay}

The test of trypan blue dye exclusion is used to count the number of viable cells. It is based on the principle that live cells possess intact cell membranes that exclude certain dyes such as trypan blue, whereas dead cells do not. The cell suspension is mixed with the dye and then visually examined to determine whether cells take up or exclude the dye. Briefly, $50 \mu \mathrm{L}$ of cell suspension was mixed with equal parts of $0.4 \%$ trypan blue (Biosera-USA) added to the cell suspension to obtain a 1: 2 dilution and mix by pipetting up and down, then incubated for less than three minutes at room temperature. Then, $20 \mathrm{~mL}$ of the mix was loaded into each chamber of the hemocytometer. Counts were performed in triplicate by one analyst 
under 40X magnification, according to the standard methodology [25].

\section{Cytotoxicity Assessment by MTT Test}

Cytotoxicity of the root of E. tehranica ethanolic extract at different concentrations assessed against Caco-2 cancer cell-line by 3-(4,5-dimethylthizol-2-yl)-2,5-diphenyltetrazolium bromide (MTT) assay. Briefly, Caco-2 cells were dispensed in a 96-well microplate at $80 \times 10^{3}$ cells per well. They treated with serial concentrations of ethanolic extract $(25,50,100,200,300,400,500,600,700,800,900$, 1000 , and $1200 \mu \mathrm{g} / \mathrm{mL}$ ). After 24 and 48 hours of incubation, cytotoxicity was measured. Each concentration was repeated three times; $100 \mu \mathrm{L}$ of MTT solution $(5 \mathrm{mg} / \mathrm{mL}$ stock solution in PBS, diluted with culture medium to the final concentration of 0.5 $\mathrm{mg} / \mathrm{mL}$ ) (Sigma-USA) added to each well to produce a total reaction volume of $250 \mu \mathrm{L}$. After four hours of incubation at $37^{\circ} \mathrm{C}$ with $5 \% \mathrm{CO}_{2}$, the supernatants were aspirated, and the formazan crystals in each well were dissolved in $50 \mu \mathrm{L}$ dimethyl sulfoxide (DMSO) (Sigma-USA). The amount of purple formazan was determined by measuring the absorbance at 570 and $630 \mathrm{~nm}$ dual wavelengths with ELISA (the enzyme-linked immunosorbent assay) reader (Model ELx800, Bio Tek, USA). Euphorbia tehranica ethanolic extract was not added to the control samples (untreated cells).

Cell viabilities were calculated using the following formula:

Cell viability rate $(\%)=\left(\mathrm{OD}_{570 / 630}\right.$ of treated cells/ OD of control cells) $\times 100 \%$.

The $\mathrm{IC}_{50}$ (half maximal inhibitory concentration) values from cytotoxicity assays were calculated from dose response curves using linear regression analysis by the JavaScript version of PolySolve (07.20.2013) software.

\section{Statistical Analysis}

Data obtained from MTT assay for different concentrations of the root of E. tehranica ethanolic extract of triplicate independent measurements within 24 and 48 hours calculated as viability rate was enacted with SPSS version 16 using one-way ANOVA followed by Tukey's HSD post-hoc test. $\mathrm{P}<0.05$ was considered as statistically significant.

\section{RESULTS}

\section{Cytotoxicity Assessment of the Root of E. tehranica Ethanolic Extract on Caco-2 Cell Line}

The current study assessed the cytotoxic effect of the root of E. tehranica ethanolic challenges culture. The effects of E. tehranica extract on the viability of human colorectal cancer cell line Caco-2 were examined in vitro by incubating the cells in $25,50,100$, $200,300,400,500,600,700,800,900,1000$, and $1200 \mu \mathrm{g} / \mathrm{mL}$ of $E$. tehranica extract for 24 and 48 hours; the cell viability was then measured by MTT assay (Figure 1). The MTT assay results showed that the growth of the treated cells decreased significantly in a concentration-dependent manner.The dose and time-dependent effect of the root of E. tehranica ethanolic extract on the growth of Caco-2 cell line was analyzed by one-way ANOVA. Comparison of the mean cell viability of treated cells in two periods of 24 and 48 hours showed a significant difference between all treated groups compared with untreated cells $(\mathrm{P}<0.001)$. Also, by increasing the concentration of the root of E. tehranica ethanolic extract, the average viability of the cells decreased.

ANOVA followed by Tukey's post-test was used for group comparisons. P values $<0.05$ were considered statistically significant. Tukey's HSD post-hoc test indicated a significant difference between 400 to $1200 \mu \mathrm{g} / \mathrm{mL}$ treated concentrations and control group (untreated cells) in 24 hours; also there was a significant difference between 200 to $1200 \mu \mathrm{g} / \mathrm{mL}$ treated concentrations and the control group (untreated cells) in 48 hours $(\mathrm{P}<0.001)$.

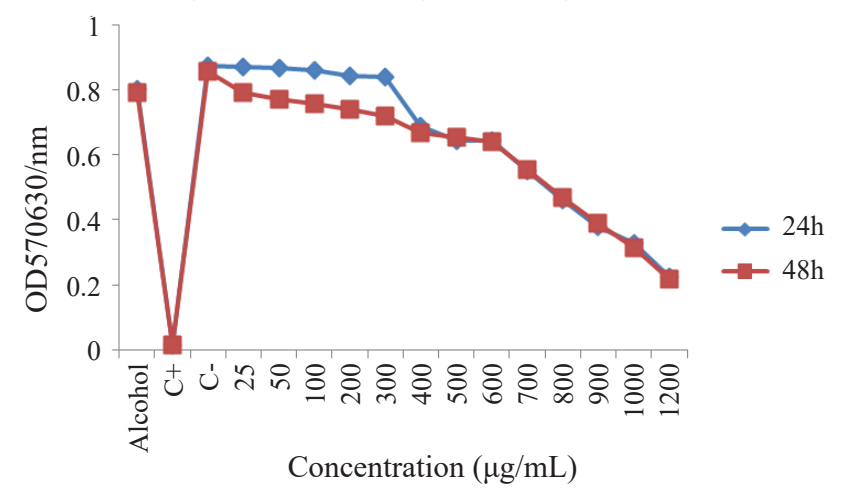

Figure 1: The Effect of The Root of E.tehranica Ethanolic Extract at to $1200 \mu \mathrm{g} / \mathrm{mL}$ Concentrations on Caco-2 Human Colorectal Cancer Cell Line 24 Hours and 48 Hours of Incubation. Cell viability was determined by MTT Assay. Alcohol as a solvent control, $\mathrm{C}^{+}$: treated cells with DMSO $20 \%$ as a positive control, $\mathrm{C}:$ untreated cells as a negative control. 
Anticancer Activity Against Caco-2 Colorectal Cancer Cell Line

Twenty-four hours after treatment with the root of E. tehranica ethanolic extract, Caco-2 cells viability decreased in a concentration-dependent manner. The viability of Caco-2 cells significantly decreased in 400 to $1200 \mu \mathrm{g} / \mathrm{mL}$ concentrations, compared with untreated cells of the control group $(\mathrm{P}<0.001)$ (Figure 2). The highest inhibition of the cell growth was observed after treatment with the root of E. tehranica ethanolic extract at 1000 and $1200 \mu \mathrm{g} / \mathrm{mL}$ concentration approximately $62.6 \%$ and $74.4 \%$, respectively. Fourth-eight hours after treatment with the root of E. tehranica ethanolic extract, Caco-2 cells viability decreased in a concentration-dependent manner. The viability of Caco- 2 cells significantly decreased in 200 to $1200 \mu \mathrm{g} / \mathrm{mL}$ concentrations compared

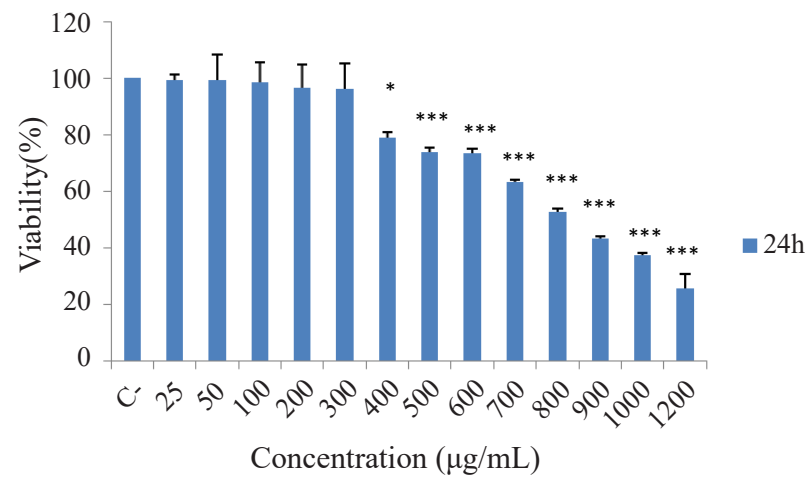

Figure 2: Anticancer Activity of the Root of E. tehranica Ethanolic Extract on Caco-2 Cell Line. Cells were incubated with ethanolic extract ( 25 to $1200 \mu \mathrm{g} / \mathrm{mL}$ ) at $37^{\circ} \mathrm{C}$ for 24 hours. Cells viabilities were evaluated using MTT assays and calculated as a ratio of the control. Data represent the means (SD) of three independent experiments. * Significant reduction in cell viability at $\mathrm{P}<0.05$, and $* * *$ Significant reduction in cell viability at $\mathrm{P}<0.001$, compared with that of the control group.

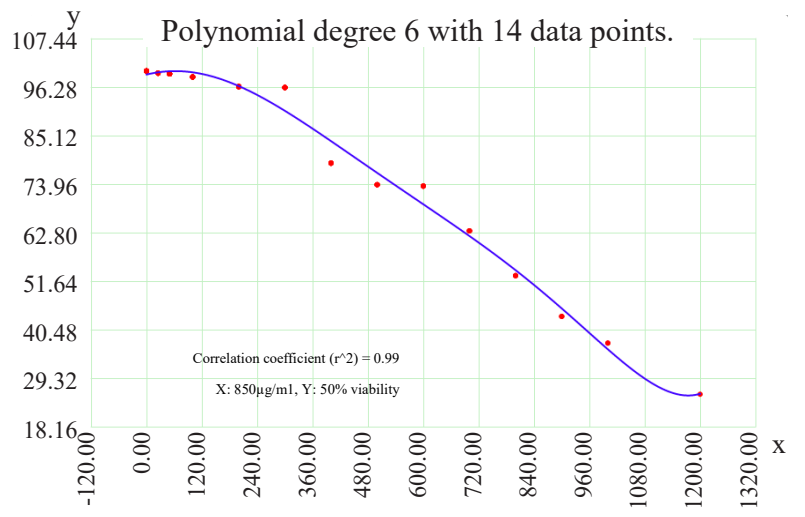

with untreated cells as the control group $(\mathrm{P}<0.001)$ (Figure 3). The highest inhibition of growth was observed after treatment with the root of E. tehranica ethanolic extract at 1000 and $1200 \mu \mathrm{g} / \mathrm{mL}$ concentrations approximately $63.2 \%$ and $74.4 \%$, respectively. The root of E. tehranica ethanolic extract inhibited Caco-2 cell line proliferation in a time and concentration-dependent manner.

\section{The $\mathrm{IC}_{50}$ Was Calculated for the Root of $E$. tehranica Ethanolic Extract}

The effective concentration of the root of E. tehrani$c a$ ethanolic extract to determine the $\mathrm{IC}_{50}$ value was obtained by regression analyses of concentration-inhibition curves (Figure 4). The $\mathrm{IC}_{50}$ value was 850 $\mu \mathrm{g} / \mathrm{mL}$ for 24 hours, and $855 \mu \mathrm{g} / \mathrm{mL}$ for 48 hours after treatment.

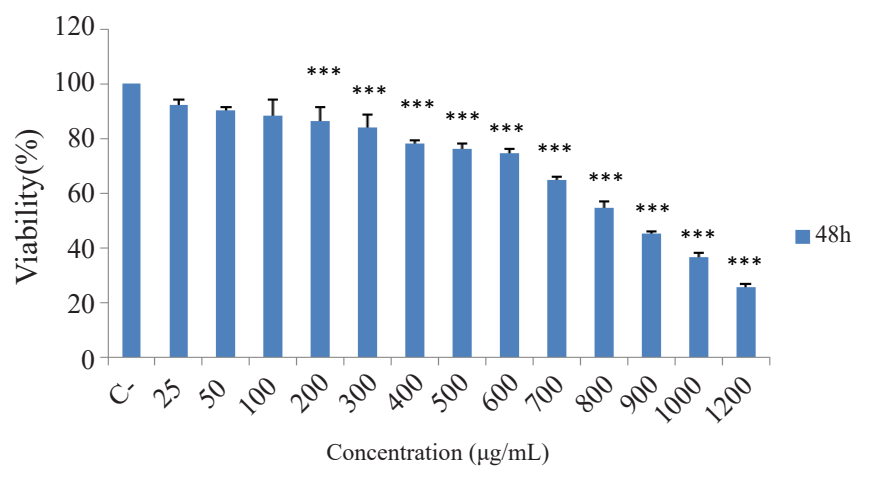

Figure 3: Anticancer Activity of the Root of E. tehranica Ethanolic Extract on Caco-2 Cell Line. Cells were incubated with ethanolic extract ( 25 to $1200 \mu \mathrm{g} / \mathrm{mL}$ ) at $37^{\circ} \mathrm{C}$ for 48 hours. Cells viabilities were evaluated using MTT assays and calculated as a ratio of the control. Data represent the means (SD) of three independent experiments. $* * *$ Significant reduction in cell viability at $\mathrm{P}<0.001$, compared with that of the control.

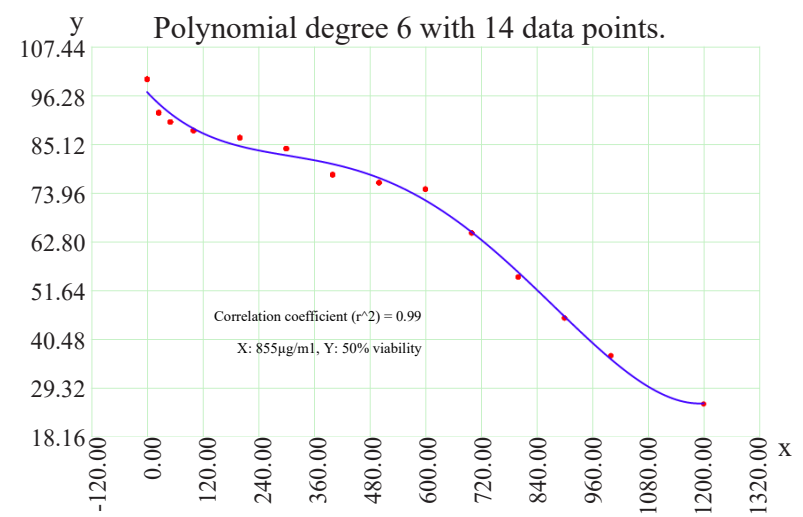

Figure 4: Regression Analyses to Calculate the $\mathrm{IC}_{50}$ Values of The Root of E. tehranica Ethanolic Extract. The horizontal axis $(\mathrm{x})$ represents the concentration $(\mu \mathrm{g} / \mathrm{mL})$ and the vertical axis $(\mathrm{y})$ represents the percentage of the viability cells. The $\mathrm{IC}_{50}$ value was $850 \mu \mathrm{g} / \mathrm{mL}$ for the 24 hours after treatment and $855 \mu \mathrm{g} / \mathrm{mL}$ for 48 hours after treatment. 


\section{DISCUSSION}

The genus Euphorbia is wide-spreading all over the world. The research on Euphorbia species show that the some plants can use in traditional medicines or revealed the new activities on modern pharmacological filed. The main biological activities of medical plants include anti-inflammatory, anticancer, antioxidant, antipyretic-analgesic, antimicrobial activity, antifeedant, and molluscicidal activities. The knowledge about the relationships between structure and activity study on diterpenoids gives more detailed information about the active core framework and substituents [5]. The research on medicinal plants and their effective compounds have been attentedin traditional medicine. They might be possibly used in therapy, after pharmacological and toxicological studies

Over the years, natural products are used as promising sources to discover new pharmaceutical agents $[26,27]$. Medicinal plants contain powerful comf pounds in any of the parts, including the bark, stem, resin, leaf, root, flower, fruit, and seed. Such healing properties of plants cure various health problems [28]. Euphorbia teheranica Boiss. (Euphorbiaceae) is a plant widespread in Tehran region and semi-desert areas of central Iran [13]. Nevertheless, there are no studies on the effect of ethanolic extract of this plant in cancer. The current study aimed at analyzing the anticancer activity of the root of E. tehranica ethanolic extract.

Cancer is a class of diseases characterized by unregulated cell growth. The World Health Organization (WHO) reported that approximately $13 \%$ of all deaths in the world are caused by cancer each year [29]. Death from colon cancer is the fourth highest among all cancer-related deaths. In the current study, the human colon cancer cell-line Caco-2 was used as the target. The current study observed that the root of E. tehranica ethanolic extract induced strong cytotoxic effects, which decreases the viability and growth of Caco-2 cell-line. Response of cells to the drug occurred in a time and dose-dependent manner. $\mathrm{IC}_{50}$, according to the MTT assay was $850 \mu \mathrm{g} / \mathrm{mL}$ for 24 hours, and $855 \mu \mathrm{g} / \mathrm{mL}$ for 48 hours after treatment. Li et al., reported that whole plant of $E$. hirta $L$. showed significant anticancer activity on HT-29 cellline for 24 hours [28]. Also, Patil and Magdum [30], and Sidambaram et al., [31] showed that E. hirta $L$. had anti-cancer activity on EL-4 mouse lymphoma cell-line and Hep-2 human larynx epithelioma cellline, respectively. Prakash and Gupta showed the anticancer effects of ethanolic extract of three plant species namely Ricinus communis Linn, Euphorbia helioscopia, Jatropha curcas of the family Euphorbiaceae against seven human cancer cell lines [32]. Haq et al., reported that the crude methanolic root extract of Euphorbia wallichii and its fractions had antioxidant and cytotoxic activities on human cancer cell lines [33]. Sreenika et al., reported the antioxidant and antitumor activity of Ethyl acetate extract of Euphorbia milii against breast cancer in vivo and colon cancer in mice [34]. Therefore, findings of the current study, in agreement with the above information, demonstrated a wide range of anti-cancer properties of Euphorbia extract.

The current study indicated that the root of E. tehranica ethanolic extract had cytotoxicity and anticancer activities. The current study findings demonstrated that the root of E. tehranica ethanolic extract was capable of inhibiting growth in Caco-2 cell lines. Future studies are needed to evaluate its molecular mechanisms of action according to anticancer activities. The current results suggested that the root of E. tehranica ethanol extract had potent anticancer effects. Taken together, these results suggested that ethanolic extract of the E. tehranica may impart interesting biological effects on the cancer cells, which may represent a potential source of chemopreventive agents.

\section{ACKNOWLEDGMENTS}

The authors would like to thank the Research Institute for Gastroenterology and Liver diseases of Shahid Beheshti University of Medical Sciences for its support.

\section{CONFLICT OF INTEREST}

The authors declared no conflict of interests regarding the publication of the paper.

\section{ETHICS APPROVAL}

The Ethics Committee of Department approved the protocol of the study.

\section{REFERENCES}

1. Gruenwald J. The Global Herbs \& Botanicals Market. http://www.nutraceuticalsworld. com/issues/2008-07/view_features/the-global-herbs-amp-botanicalsmarket/. (accessed on 10 December 2013). 2013.

2. Altundağ E, Öztürk M. Ethnomedicinal studies on the plant resources of East Anatolia, Turkey. Procedia Soc Behav Sci. 2011;19:756-77. https://doi.org/10.1016/j.sbspro.2011.05.195

3. Tang $\mathrm{Q}$, Su Z, Han Z, Ma X, Xu D, Liang $\mathrm{Y}$, et al. LC-MS method for detecting pros- 
tratin in plant extracts and identification of a high-yielding population of Euphorbia fischeriana. Phytochem Lett. 2012;5:214-8. https://doi.org/10.1016/j.phytol.2011.12.011

4. Jassbi AR. Chemistry and biological activity of secondary metabolites in Euphorbia from Iran. Phytochem. 2006;67(18):1977-84. https://doi.org/10.1016/j.phytochem.2006.06.030 PMID: 16889806

5. Shi QW, Su XH, Kiyota H. Chemical and pharmacological research of the plants in genus Euphorbia. Chem Rev. 2008;108(10):4295-327. https://doi.org/10.1021/cr078350s

6. Parsa A. Euphorbiaceae. Flore de 1' Iran, Tehran. 1949;4:1206-84.

7. Pahlevani AH. Euphorbia prostrata, a noteworthy new record from the flora of Iran. Rostaniha 2006;7(2):157-8.

8. Akhani H. A new spiny, cushion-like Euphorbia (Euphorbiaceae) from south-west Iran with special reference to the phytogeographic importance of local endemic species. Bot J Linn Soc. 2004;146(1):107-21. https://doi.org/10.1111/j.1095-8339.2004.00310.x

9. Rechinger KH. Euphorbia. In: Flora Iranica, Euphorbiacea. 6nd ed. Graz: Akademische Druck Verlagsanstalt; 1964. p. 48.

10. Mobayen S. Rostanihaye Iran. Vol 2. Tehran: Tehran University press; 1979. p.85-151.

11. Nasseh Y, Joharchi MR. New records and interesting taxa of Euphorbiaceae from Iran. Iran J Bot. 2004;10:189-93. http://www.sid.ir/En/Journal/ViewPaper.aspx?ID=99227.

12. Nasseh Y, Joharchi MR, Zehzad B. Two new records of the genus Euphorbia (Euphorbiaceae) for the flora of Iran. Iran J Bot. 2006;12(1):7881.

13. Rechinger KH. Euphorbia. In: Flora Iranica, Euphorbiacea. 6nd ed. Graz: Akademische Druck Verlagsanstalt; 1964. p. 33.

14. World Health Organization. Cancer Incidence in Five Continents. Lyon: The World Health Organization and The International Agency for Research on Cancer. 2002. https://www.iarc.fr/en/ publications/pdfs-online/epi/sp155/CI5V8.pdf

15. Boyle P, Langman JS. ABC of colorectal cancer: Epidemiology. BMJ. 2000;321(7264):8058.https://doi.org/10.1136/bmj.321.7264.805 PMID:11009523 PMCID:PMC1118620

16. World Cancer Research Fund and American Institute for Cancer Research. Food, Nutrition, Physical Activity, and the Prevention of Cancer: A Global Perspective. Washington, DC: Ameri- can Institute for Cancer Research. 2007.

17. Fakheri H, Janbabai G, Bari Z, Eshgi F. The epidemiologic and clinicalpathologic characteristics of colorectal cancers from 1999 to 2007 in Sari, Iran J Mazandaran Univ Med Sci. 2008;18(67):58-66. http://jmums.mazums.ac.ir/article-1-493-en.html.

18. Haghdoost AA, Chamani G, Zarei MR, Rad MB, Hashemipoor M, Marzban M. Low incidence of colorectal cancer in Kerman province, Iran. Iran J Cancer Prev. 2011;4(1):33-7. http://journals. sbmu.ac.ir/cp/article/view/2424/2103.

19. Moghimi-Dehkordi B, Safaee A, Zali MR. Prognostic factors in 1,138 Iranian colorectal cancer patients. Int J Colorectal Dis. 2008;23(7):683-8. https://doi.org/10.1007/s00384-008-0463-7

20. Dolatkhah R, Somi MH, Bonyadi MJ, Kermani IA, Farassati F, Dastgiri S. Colorectal cancer in Iran: molecular epidemiology and screening strategies. J Cancer Epidemiol. 2015;2015:643020.

21. Janout V, Kolla' rova' H. Epidemiology of colorectal cancer. Biomed Pap Med Fac Univ Palacku Olomouc Czech Repub. 2001;145:5-10. https:// doi.org/10.5507/bp.2001.001 PMID:12415635

22. U.S. Cancer Statistics Working Group. United States Cancer Statistics: 1999-2005 Incidence and Mortality Web-based Report. Atlanta, GA: US Department of Health and Human Services, Centers for Disease Control and Prevention \& National Cancer Institute. 2009.

23. Özbilgin S, Çitoğlu G. Use of some Euphorbia species in traditional medicine in Turkey and their biological activities. Turk J Pharm Sci. 2012;9(2):241-56.

24. Whelan LC, Ryan MF. Ethanolic extracts of Euphorbia and other ethnobotanical species as inhibitors of human tumour cell growth. Phytomedicine.2003;10(1):53-8.https://doi. org/10.1078/094471103321648665

25. Louis KS, Siegel AC, Levy GA. Comparison of manual versus automated trypan blue dye exclusion method for cell counting, in: M.J. Stoddart (Ed.), Mammalian Cell Viability: Methods and Protocols. Series Methods in Molecular Biology. New York: Springer Protocols; 2011.p.712. https://doi.org/10.1007/978-1-61779-108-6 2 PMCID:PMC3246739

26. Bankova V. Natural products chemistry in the third millennium. Chem Cent J. 2007;1:1. https:// doi.org/10.1186/1752-153X-1-1

27. Manach C, Hubert J, Llorach R, Scalbert A. The complex links between dietary phytochemicals and human health deciphered by metabolomics. Mol Nutr Food Res. 2009;53(10):1303-15. 
https://doi.org/10.1002/mnfr.200800516

28. Li C, Wang MH. In vitro biological evaluation of 100 selected methanol extracts from the traditional medicinal plants of Asia. Nutr Res Pract. 2014;8(2):151-7. https://doi.org/10.4162/nrp.2014.8.2.151

29. Vij T, Prashar Y, jain D. An updated review on cancer. Int J Clin Pharmacol Res. 2014;4(2):91102. http://www.ijprjournal.org/viw/4/2

30. Patil SB, Magdum C. Phytochemical investigation and antitumour activity of Euphorbia hirta Linn. Eur J Exp Biol. 2011;1:51-6. www.pelagiaresearchlibrary.com.

31. Raja Sidambaram R, MG Dinesh, Jayalakshmi E. An in vitro study of cytotoxic activity of Euphorbia hirta on Hep-2 cells of human epithelioma of larynx. Int J Pharm Pharm Sci.
2011;3:101-3.

32. Prakash E, Gupta DK. Cytotoxic Activities of Extracts of Medicinal Plants of Euphorbiacae Family Studied on Seven Human Cancer Cell lines. Univers J Plant Sci. 2013;1(4):113-7. https://doi.org/10.13189/ujps.2013.010401.

33. Haqa IU, Ullaha N, Bibia G, Kanwala S, Ahmadb MS, Mirzaa B. Antioxidant and Cytotoxic Activities and Phytochemical Analysis ofEuphorbia wallichii Root Extract and its Fractions. Iran J Pharm Res. 2012;11(1):241-9.

34. Sreenika G, Naga Sravanthi K, Lakshmi BVS, Thulja P, Sudhakar M. Antioxidant And Antitumor Activity Of Euphorbia Milii Flower Extract Against In Vivo Breast Cancer And Colon Cancer In Mice. World J Pharm Pharm Sci. 2015;4(06):912-34. 